\title{
Article \\ Micro-Aid Liquid 10 Promotes Growth Performance and Health Status of White Shrimp, Litopenaeus vannamei
}

\author{
Kuo-Chin Huang ${ }^{1}$, Jai-Wei Lee ${ }^{1}$, Ya-Li Shiu ${ }^{2}$, Rolissa Ballantyne ${ }^{1}\left[\right.$ and Chun-Hung Liu ${ }^{2,3, * \mathbb{C}}$ \\ 1 Department of Tropical Agriculture and International Cooperation, National Pingtung University of Science \\ and Technology, Pingtung 912, Taiwan; keven@gofarco.com.tw (K.-C.H.); joeylee@mail.npust.edu.tw (J.-W.L.); \\ rolissa12@gmail.com (R.B.) \\ 2 Department of Aquaculture, National Pingtung University of Science and Technology, Pingtung 912, Taiwan; \\ et111519@gmail.com \\ 3 Research Center for Animal Biologics, National Pingtung University of Science and Technology, \\ Pingtung 912, Taiwan \\ * Correspondence: chliu@mail.npust.edu.tw
}

Citation: Huang, K.-C.; Lee, J.-W.; Shiu, Y.-L.; Ballantyne, R.; Liu, C.-H. Micro-Aid Liquid 10 Promotes Growth Performance and Health Status of White Shrimp, Litopenaeus vannamei. J. Mar. Sci. Eng. 2022, 10, 49. https://doi.org/10.3390/jmse10010049

Academic Editor: Francesco Tiralongo

Received: 29 November 2021 Accepted: 31 December 2021 Published: 2 January 2022

Publisher's Note: MDPI stays neutral with regard to jurisdictional claims in published maps and institutional affiliations.

Copyright: (C) 2022 by the authors. Licensee MDPI, Basel, Switzerland. This article is an open access article distributed under the terms and conditions of the Creative Commons Attribution (CC BY) license (https:// creativecommons.org/licenses/by/ $4.0 /)$.

\begin{abstract}
An experiment was conducted to evaluate the effects of the Micro-Aid Liquid 10 (MAL10) (DPI Global, Porterville, CA, USA), a product made from yucca extract, on growth performance, gut microbiota, and resistance of white shrimp, Litopenaeus vannamei against infectious disease caused by Vibrio alginolyticus. MAL10 was added to shrimp rearing water at different levels of 0 (control), $0.25 \mathrm{~mL} \mathrm{~m}^{3-1}$ (W0.25), $0.5 \mathrm{~mL} \mathrm{~m}^{3-1}$ (W0.5), $1 \mathrm{~mL} \mathrm{~m}^{3-1}$ (W1), and $5 \mathrm{~mL} \mathrm{~m}^{3-1}$ (W5), respectively, once per week for 70 days. Growth performances, including final body weight, specific growth rate, average daily growth and percentage of weight gain, were significantly improved by adding the MAL10 at levels up to $5 \mathrm{~mL} \mathrm{~m}{ }^{3-1}$, which may be due to the proliferation of B cells in hepatopancreas of MAL10-treated shrimp. No significant differences in the total viable count and Vibrio-like count in the gut of shrimp were recorded by spread plate method. In the challenge test, shrimp reared in the water supplemented with MAL10 at levels of $1-5 \mathrm{~mL} \mathrm{~m}^{3-1}$ had significantly lower cumulative mortality after a challenge test with $V$. alginolyticus compared to shrimp reared in the control, W0.25 and W0.5 groups. Next-generation sequencing indicated that the relative distribution of phylum Proteobacteria in control $(80.4 \%)$ was higher than the W $(77.4 \%)$. The proportion of Vibrio was primarily dominant genera in the shrimp intestine and highest in the control group compared to the W group, followed by Spongiimonas, Motilimonas, Demequina, and Shewanella genera. Although there was no statistically significant difference, higher $\alpha$-diversity indices were recorded in the W5-treated group than in the control group. Therefore, it is considered that MAL10 could be used as a natural alternative in shrimp aquaculture to reduce the risk of infectious disease caused by pathogenic Vibrio and improve the growth performance of white shrimp.
\end{abstract}

Keywords: white shrimp; disease resistance; growth performance; Micro-Aid; yucca extract; saponin

\section{Introduction}

Generally, aquaculture production has been steadily increasing with high demand for seafood. Moreover, demand is expected to grow significantly due to various social and economic factors, namely, population growth, rising incomes, and improved supply chain distribution. Among the main groups of seafood production, white shrimp, Litopenaeus vanname $i$ is currently the most economically valuable crustacean species dominating aquaculture production worldwide. According to Food and Agriculture Organization (FAO) [1], crustaceans represented $11.4 \%$ of the total production in aquaculture, of which the white shrimp contributed $52.9 \%$. Unfortunately, the intensive shrimp aquaculture increases environmental stressors that increase the risk of infectious disease outbreaks and impose significant losses in productivity. Vibriosis is one of the primary disease problems in shrimp aquaculture caused by Vibrio alginolyticus, V. harveyi, V. parahaemolyticus, among others, 
are responsible for reducing the capacity of immune response and causing catastrophic losses [2-4]. Therefore, it is becoming a global issue to find a strategy to reduce the problem of shrimp disease.

Plant-based products have received much attention in aquaculture as effective strategies for controlling shrimp diseases instead of antibiotics [5,6]. Plant-based products are highly nutritional, with antimicrobial, anti-inflammatory, and anti-oxidative properties available in aquaculture. Moreover, plants have been used as prophylactic and therapeutic agents, deemed more effective, safer, promote growth, intestinal health, and reduce disease outbreaks. In addition, various plant extracts have been evaluated to stimulate crustacean's health status $[7,8]$. These benefits arise from several bioactive compounds including flavonoids, phenols, polysaccharides, essential oils, organic acids, saponins, alkaloids, glycosides, tannins, terpenoids, and steroids [9]. Research and development efforts to use different plant-based products to address challenges associated with diseases are ongoing to arrive at a viable solution.

Among these compounds, saponins extracted from Quillaja saponaria (soapbark tree) and Yucca schidigera are known for their beneficial effects when applied in aquaculture and livestock as natural growth promoters [10,11]. Although the biological effects of saponins, including growth, cholesterol metabolism, immune system, and antifungal activities on various aquatic animals, have been studied, many of them used $Q$. saponaria [12,13]. In addition to the above beneficial effects, saponin extracted from the $Y$. schidigera also has the potential to reduce nitrogen $(\mathrm{N})$ pollution in livestock and aquaculture industries $[14,15]$. Saponins are a diverse group of extracts widely distributed in the plant kingdom, characterized by their structure comprising a triterpene or steroid aglycone and one or multiple sugar chains [16]. The main application of saponins as a feed additive in animal nutrition or added in water proved positive effects on the growth rates, reduction in ammonia, and fecal odors in animal excreta $[17,18]$. However, the bacterial diversity of saponins in shrimp intestines has never been assessed.

Micro-Aid (DPI Global; Porterville, CA, USA) is manufactured from a purified extract of $Y$. schidigera plant and contains saponins, which have ruminal and systemic immunological benefits and promote growth of livestock [11,19]. However, little is known about its application in aquaculture. Therefore, this study investigated the impact of Micro-Aid Liquid 10 (MAL10) supplementation on the growth performance, intestinal microbial diversity, and disease resistance of white shrimp against $V$. alginolyticus. The MAL10 has beneficial effects on white shrimp, including growth performance and disease resistance against $V$. alginolyticus via the alteration of gut microbiota.

\section{Materials and Methods}

\subsection{Animal}

The juvenile shrimp were selected from a farm at the Department of Aquaculture, National Pingtung University of Science and Technology (NPUST) in Taiwan. Thereafter, shrimp were acclimated in a $10 \mathrm{~m}^{3}$ cement tank with $5 \mathrm{~m}^{3}$ of aerated water (25 ppt) pretreated by biochar [20] at $28^{\circ} \mathrm{C}$. During the acclimation, shrimp were fed the basal diet at $\sim 5 \%$ of body weight (Table 1 ) twice daily for 2 weeks prior to the experiment.

Table 1. Ingredients of the basal diet $\left(\mathrm{g} \mathrm{kg}^{-1}\right)$ used for culturing Litopenaeus vannamei.

\begin{tabular}{cc}
\hline Ingredients & Amount $\mathbf{( g ~ \mathbf { ~ g } ^ { - \mathbf { 1 } } )}$ \\
\hline Fish meal & 370 \\
Soybean meal & 300 \\
$\alpha$-starch & 200 \\
Shrimp meal & 47 \\
*Vitamin mix & 25 \\
*Mineral mix & 25 \\
Fish oil & 33 \\
\hline
\end{tabular}

* Vitamin and mineral pre-mix prepared according to Tseng et al. [21]. 


\subsection{Experimental Design and Growth Trial}

MAL10, a commercial product (DPI Global; Porterville, CA, USA) extracted from $Y$. schidigera plant that contains the bioactive compound saponin, was applied in this study. The MAL10 was added to the shrimp rearing water at 0 (control), 0.25, 0.5, 1, and $5 \mathrm{~mL} \mathrm{~m}^{3-1}$ once per week (designated as W0.25, W0.5, W1, and W5, respectively). The growth performance, gut microbiota, and disease resistance of white shrimp were assessed after 70 days of rearing. The trial was carried out in $2 \mathrm{~m}^{3}$ cement tanks $\left(1.2 \times 1.9 \times 1.2 \mathrm{~m}^{3}\right)$ on the aquafarm, NPUST, Pingtung, Taiwan. Each treatment was carried out in triplicates ( $n=3$ tanks) and each tank contained 50 shrimp (initial mean weight: $0.55 \pm 0.03 \mathrm{~g}$ ) (stock density: 21.9 shrimp per $\mathrm{m}^{3}$ ). The diet used to feed shrimp (sinking feed) was prepared based on the nutritional requirement of white shrimp (crude protein: $37 \%$; crude fat $7 \%$ ) according to the method of Tseng et al. [21] (Table 1). Feed ingredients were ground up and then passed through a \#60-mesh screen. Thereafter, sufficient distilled water was supplied to the mixture to render a stiff dough. A food grinder with a die diameter of $\sim 1 \mathrm{~mm}$ was used to prepare pellets $\sim 1 \mathrm{~mm}$ in length. Pellets were dried in an oven at $80{ }^{\circ} \mathrm{C}$ until the moisture was $<10 \%$. The dried feeds were stocked at $4{ }^{\circ} \mathrm{C}$ until use. The proximate composition of diet was as follows: crude protein: $36.5 \%$; crude lipid: $7.11 \%$; ash: $12.6 \%$; moisture: $7.2 \%$.

The growth trial was conducted for 70 days. Shrimp were fed twice daily at a ratio of $3 \sim 5 \%$ to their body weight (the amount of feed for shrimp was adjusted according to the mean body weight measured every two weeks). Unconsumed feed was dried in an oven at $80^{\circ} \mathrm{C}$ for calculating daily feed intake by subtracting the unconsumed portion from the total amount fed. During the trials, ammonia-N and nitrite- $\mathrm{N}$ were measured every 2 weeks. At the end of growth trials, shrimp were harvested and individually weighed. The feed efficiency (FE), percentage of weight gain (PWG), specific growth rate (SGR), average daily growth (ADG), and survival were calculated as:

$\mathrm{FE}=$ weight gain/total feed intake;

PWG $(\%)=($ (final body weight - initial body weight $) /$ initial body weight $) \times 100$;

SGR $(\%)=($ ln final body weight $-\ln$ initial body weight $) /$ days $\times 100$;

ADG (g shrimp ${ }^{-1}$ day $\left.^{-1}\right)=($ final body weight - initial body weight $) /$ days;

Survival $(\%)=($ final number of shrimp $/$ initial number of shrimp $) \times 100$.

Moreover, shrimp were sampled for the challenge test with the pathogen, V. alginolyticus. Histological examination of the digestive tracts, intestinal bacteria counts, and characterization of intestinal microbiota community was analyzed using 16S rRNA nextgeneration sequencing (NGS) after the feeding trial.

\subsection{Histological Examination of the Intestine and Hepatopancreas}

Samples for histological examination of intestine and hepatopancreas were immersed in phosphate-buffered formalin (10\%, pH 7.2), subsequently dehydrated and embedded in paraffin according to standard histological procedures, and hematoxylin- and eosin-stained sections were prepared on glass slides. Hepatopancreas, and villi height and muscular thickness of intestinal sections were examined under a light microscope (Leica DMIL, Leica Microsystems, Wetzlar, Germany). The images were analyzed using the ToupView 2300AC (Leader Scientific Co., Ltd., New Taipei City, Taiwan).

\subsection{Resistance to Vibrio Pathogens}

Shrimp were challenged with $V$. alginolyticus [22] to assess the health status of shrimp. The bacteria were cultured in tryptic soy broth (TSB, Difco, Sparks, Md, USA) supplemented with $2 \% \mathrm{NaCl}$ for $24 \mathrm{~h}$ at $28{ }^{\circ} \mathrm{C}$. Bacteria were collected by centrifugation at $7000 \times g$ for $15 \mathrm{~min}$ at $4{ }^{\circ} \mathrm{C}$, and then the pellet was resuspended in $0.85 \% \mathrm{NaCl}$ and adjusted to $10^{7} \mathrm{cfu} \mathrm{mL}^{-1}$ as a stock solution by measuring the absorbance at optical density (OD) of $595 \mathrm{~nm}\left(1.0=\sim 10^{9} \mathrm{cfu} \mathrm{mL}^{-1}\right)$. The bacteria were diluted to three concentrations of $2 \times 10^{7} \mathrm{cfu} \mathrm{mL}^{-1}, 2.5 \times 10^{7} \mathrm{cfu} \mathrm{mL}^{-1}$, and $3.5 \times 10^{7} \mathrm{cfu} \mathrm{mL}^{-1}$ as stock solutions used for the injection of shrimp in the C, W0.25 and W0.5, and W1 and W5, respectively. Shrimp 
were starved for $24 \mathrm{~h}$ before the challenge test. Then, shrimp that weighed $\sim 2 \mathrm{~g}, \sim 2.5 \mathrm{~g}$, and $\sim 3.5 \mathrm{~g}$ from the $\mathrm{C}, \mathrm{W} 0.25$, and W0.5, and W1 and W5, respectively, were selected for the challenge test. Thirty shrimp from each group were injected with $10 \mu \mathrm{L}$ of bacterial solution into the ventral sinus resulting in $10^{5} \mathrm{cfu}(\mathrm{g} \text { shrimp })^{-1}$. Another $30 \mathrm{shrimp}$ from the control group were injected with $10 \mu \mathrm{L}$ of $0.85 \% \mathrm{NaCl}$ and served as the unchallenged control. After bacterial or saline solution injections, the site of injection was pressed by finger for $20 \mathrm{~s}$ to prevent hemolymph leaking and then wiped with sterile $75 \%$ alcohol cotton. Each treatment was carried out in triplicate with 10 shrimp per replicate. After the injection, shrimp were held in a separate $60 \mathrm{~L}$ glass aquarium with $40 \mathrm{~L}$ of seawater $(25 \%$ ) and aeration. During this trial, one-half of the water was changed and mortalities were recorded daily.

\subsection{Analysis of Intestinal Microbiota Counts}

At the end of feeding trials, 6 shrimp at intermolt stage were selected from each group and placed in a $60 \mathrm{~L}$ glass aquarium, starved for $24 \mathrm{~h}$ to empty their intestines. The whole intestines $(0.01-0.022 \mathrm{~g})$ of shrimp were dissected using sterilized surgical scissors and then homogenized in sterile saline. The homogenized liquid was serially diluted in sterile saline $(0.85 \% \mathrm{NaCl})$, and then $100 \mu \mathrm{L}$ diluted solution was spread on triplicate plates of Vibrio-selective medium (thiosulfate citrate bile-salt sucrose (TCBS) agar, Difco, Sparks, Md, USA) to determine the Vibrio-like count (VBCs), and tryptic soy broth (TSB) agar to determine the total viable count. All plates were incubated at $27^{\circ} \mathrm{C}$, and colonies were numerated daily for 1 week.

\subsection{Next-Generation Sequencing (NGS) of $16 S$ rDNA Gene Amplicons and Taxonomic Classification}

Due to the lowest mortality of shrimp in the W5 group after pathogen injection, shrimp from the control and W5 were sampled for the NGS of 16S rDNA gene amplicons, and designated as C and W5, respectively. Only shrimp at the intermolt stage were used for this analysis.

DNA of the whole intestine was isolated in triplicates (each replicate contained the intestines pooled from three shrimp) using a FavorPrepTM Tissue Genomic DNA extraction Mini Kit (Favorgen Biotech, Pingtung, Taiwan) according to the manufacturer's instruction. The DNA purity was analyzed by a NanoDrop spectrophotometer and only DNA samples with the absorbance at $260 / 280 \mathrm{~nm}$ within the range of 1.8 2.0 were used for further analyses. A SureCycler 8800 (Agilent Technologies, CA, USA) was used to amplify the region of V3-V4 of the 16S rRNA gene with specific primers: the forward primer (S17): 5'-TCGTCGGCAGCGTCAGATGTGTATAAGAGACAGCCTACGGGNGGCWGCAG-3' ${ }^{\prime}$ and reverse primer (A21): $5^{\prime}$-GTCTCGTGGGCTCGGAGATGTGTATAAGAGACAGGACTACH VGGGTATCTAATCC-3' [23] in the preparation solution (Nextera XT Index Kit, Illumina, CA, USA) ( $N$ in primer sequence means the nucleic acids could be $A, T, C$, and G; W in primer sequence means the nucleic acids could be $\mathrm{A}$, and $\mathrm{T} ; \mathrm{H}$ in primer sequence means the nucleic acids could be $\mathrm{A}, \mathrm{T}$, and $\mathrm{G}$; V in primer sequence means the nucleic acids could be A, C, and G). Each forward and reverse primer for V3-V4 amplification of samples were $5^{\prime}$-barcode-tagged with an 8-bp specific DNA sequence. The 4200 TapeStation (Agilent Technologies) was used to check the size of amplified products. After library construction, sequences of $2 \times 300$-bp paired-end reads were amplified in a MisSeq Reagent kit v3 (600-cycle) (Illumina, CA, USA) with the NGS sequencer, Illumina MiSeq ${ }^{\circledR}$ platform (Illumina). Bowtie 2, an ultrafast and memory-efficient tool for aligning sequencing reads with long reference sequences, was used to align the Illumina paired-end reads with long reference sequences. Sequences were filtered, inferior quality sequences were removed, and sequences of barcode-tagged primers were trimmed off. Overlapping pair-end reads of sequence were joined using FLASH. Mothur was used to filter potential chimeric sequence. The effective reads and corresponding clean reads were in a range of $95.12 \sim 97.7 \%$. The UPARSE algorithm derived from USEARCH v7.0.1090 was used to group sequences into 
operational taxonomic units (OTUs), and sequences from each OTU that agreed were created. The Ribosomal Database Project (RDP) classifier was employed for classifying OTU sequences into taxa after an analysis of the bacterial community. Taxonomic levels from phylum to genus were analyzed, and the clustering results were visualized by observing a principal component analysis (PCA) plot. The principle of data analysis was used to determine the extent of microbial population overlap among the dietary groups [24].

\subsection{Biodiversity and Abundances of Intestinal Microbiota}

In order to calculate genera, Pielou's evenness (J), Shannon diversity index, and Margalef's species richness (d), the alpha_diversity.py script on the website of QIIME (http: / / qiime.org/scripts/alpha_diversity.html, accessed date on 20 September 2019) were used.

\subsection{Statistical Analysis}

Experimental data were statistically analyzed by a one-way analysis of variance (ANOVA) and Duncan's multiple-range test using SAS software (Cary, NC, USA) to determine the variation and significance of differences among and between treatments, respectively. All percentage data were square-root arcsine-transformed before the statistical analysis. The level of significance was accepted at $p<0.05$.

\section{Results}

\subsection{Growth Performance}

The growth performance of shrimp cultured in water supplemented with different levels of MAL10 up to $5 \mathrm{~mL} \mathrm{~m}^{3-1}$ once per week for 70 days is shown in Table 2 and Figure 1. Survival ranged from $83.3 \%$ to $90 \%$ and did not significantly differ among the control and treatment groups. The shrimp's growth rate was significantly improved by adding MAL10 into the rearing water in a dose-dependent manner (Table 2 and Figure 1). Shrimp's growth accelerated in W5 group after 42 day of rearing as compared to that of shrimp in the control (Figure 1). At the end of growth trial, shrimp in the W5 group had the best final body weight, SGR, PWG, ADG, and FE, followed by shrimp in the W1, W0.5, W0.25, and the control. The water parameters, including ammonia- $\mathrm{N}$ and nitrite- $\mathrm{N}$ concentrations, were not significantly changed by adding MAL10 at the levels tested. The concentrations of ammonia- $\mathrm{N}$ and nitrite- $\mathrm{N}$ were all within the acceptable ranges of $0.01-0.18 \mathrm{mg} / \mathrm{L}$ and 0-0.04 mg/L, respectively. This implies that the improved growth performances of shrimp cultured in water with MAL10 were not directly related to the water quality.

Table 2. Growth performance of Litopenaeus vannamei reared in the water added with Micro-Aid Liquid 10 once per week at the levels of 0 (control), and $0.25 \mathrm{~mL} \mathrm{~m}^{3-1}$ (W0.25), $0.5 \mathrm{~mL} \mathrm{~m}^{3-1}$ (W0.5), $1 \mathrm{~mL} \mathrm{~m}^{3-1}$ (W1), and $5 \mathrm{~mL} \mathrm{~m}^{3-1}$ (W5), respectively. Data (mean $\pm \mathrm{SD}$ ) in the same rows with different superscripts are significant difference among treatments $(p<0.05) . n=3$.

\begin{tabular}{|c|c|c|c|c|c|}
\hline \multirow{2}{*}{ Parameters } & \multicolumn{5}{|c|}{ Treatments } \\
\hline & Control & W0.25 & W0.5 & W1 & W5 \\
\hline Initial weight $(\mathrm{g})$ & $0.55 \pm 0.03$ & $0.55 \pm 0.03$ & $0.55 \pm 0.03$ & $0.55 \pm 0.03$ & $0.55 \pm 0.03$ \\
\hline Final body weight (g) & $2.17 \pm 0.08^{d}$ & $2.47 \pm 0.06^{\mathrm{c}}$ & $2.55 \pm 0.11^{\mathrm{c}}$ & $3.11 \pm 0.05^{b}$ & $3.91 \pm 0.21^{\mathrm{a}}$ \\
\hline Survival $(\%)$ & $83.3 \pm 2.2$ & $84 \pm 6.2$ & $90 \pm 5.1$ & $84.7 \pm 9.09$ & $83.3 \pm 7$ \\
\hline SGR $\left(\%\right.$ day $\left.^{-1}\right)$ & $1.57 \pm 0.04^{\mathrm{d}}$ & $1.7 \pm 0.02^{c}$ & $1.73 \pm 0.04^{\mathrm{c}}$ & $1.93 \pm 0.02^{b}$ & $2.16 \pm 0.05^{\mathrm{a}}$ \\
\hline ADG (g shrimp ${ }^{-1}$ day $\left.^{-1}\right)$ & $0.023 \pm 0.001 \mathrm{~d}$ & $0.027 \pm 0.001^{\mathrm{c}}$ & $0.029 \pm 0.001^{\mathrm{c}}$ & $0.037 \pm 0.001^{b}$ & $0.048 \pm 0.001^{\mathrm{a}}$ \\
\hline Percentage of weight gain $(\%)$ & $293.8 \pm 13.9^{\mathrm{d}}$ & $348.9 \pm 10^{c}$ & $364 \pm 20.6^{c}$ & $466.4 \pm 9.9^{b}$ & $610.1 \pm 37.8^{\mathrm{a}}$ \\
\hline Feed efficiency & $0.65 \pm 0.08$ & $0.65 \pm 0.07$ & $0.69 \pm 0.02$ & $0.71 \pm 0.06$ & $0.75 \pm 0.09$ \\
\hline
\end{tabular}

Note: SGR: specific growth rate; ADG: average daily growth. 


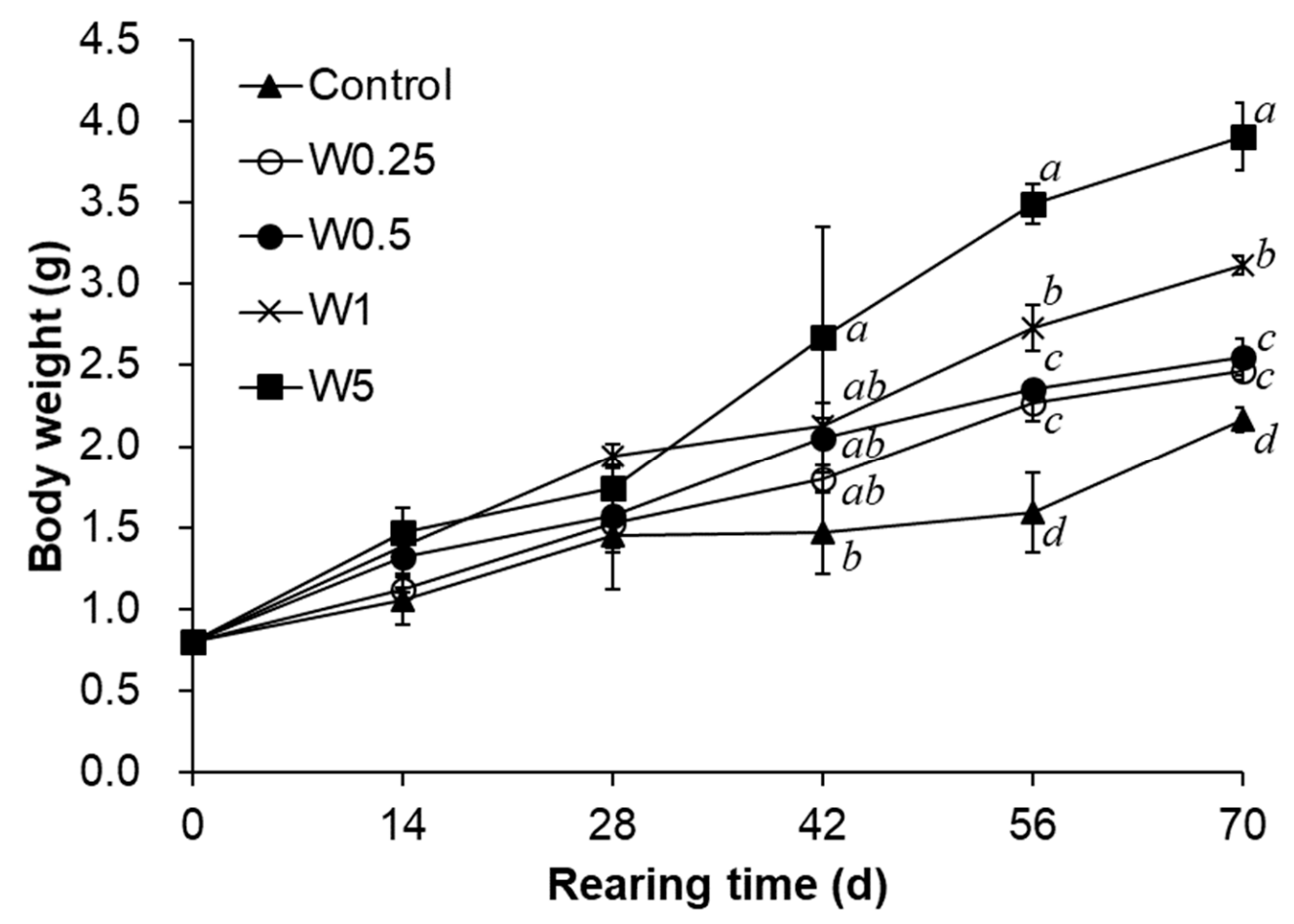

Figure 1. Growth rate of Litopenaeus vannamei reared in the water added with Micro-Aid Liquid 10 once per week at the levels of 0 (control), $0.25 \mathrm{~mL} \mathrm{~m}^{3-1}$ (W0.25), $0.5 \mathrm{~mL} \mathrm{~m}^{3-1}$ (W0.5), $1 \mathrm{~mL} \mathrm{~m}^{3-1}$ (W1) and $5 \mathrm{~mL} \mathrm{~m}^{3-1}$ (W5), respectively. Data (mean $\pm \mathrm{SD}$ ) with different letters indicate significant differences among treatments $(p<0.05) . n=3$.

\subsection{Histopathology Analysis of Hepatopancreas and Intestines of Shrimp}

Shrimp reared in water with MAL10 at a concentration up to $5 \mathrm{~mL} \mathrm{~m}^{3-1}$ appeared to have more B cells (Figure 2D,E). In addition, supplementation of MAL10 in shrimp rearing water did not influence the intestinal structures of shrimp (Figure 2F-J), and the muscular layer thickness and villi height of intestine of shrimp were not significantly different among groups (Table 3).

Table 3. Intestinal histology of Litopenaeus vannamei reared in the water supplemented with Micro-Aid Liquid 10 once per week at the levels of 0 (control), and $0.25 \mathrm{~mL} \mathrm{~m}^{3-1}$ (W0.25), $0.5 \mathrm{~mL} \mathrm{~m}^{3-1}$ (W0.5), $1 \mathrm{~mL} \mathrm{~m}^{3-1}$ (W1) and $5 \mathrm{~mL} \mathrm{~m}^{3-1}$ (W5), respectively. $n=3$.

\begin{tabular}{cccccc}
\hline & \multicolumn{5}{c}{ Treatments } \\
\cline { 2 - 6 } & Control & W0.25 & W0.5 & W1 & W5 \\
\hline Muscular layer & $32.91 \pm 2.41$ & $40.11 \pm 8.21$ & $38.9 \pm 10.4$ & $34.26 \pm 4.25$ & $40.21 \pm 6.28$ \\
thickness $(\mu \mathrm{m})$ & $43.94 \pm 6.75$ & $48.44 \pm 5.58$ & $43.89 \pm 3.60$ & $45.72 \pm 3.51$ & $49.83 \pm 4.00$ \\
Villi height $(\mu \mathrm{m})$ & 434 \\
\hline
\end{tabular}



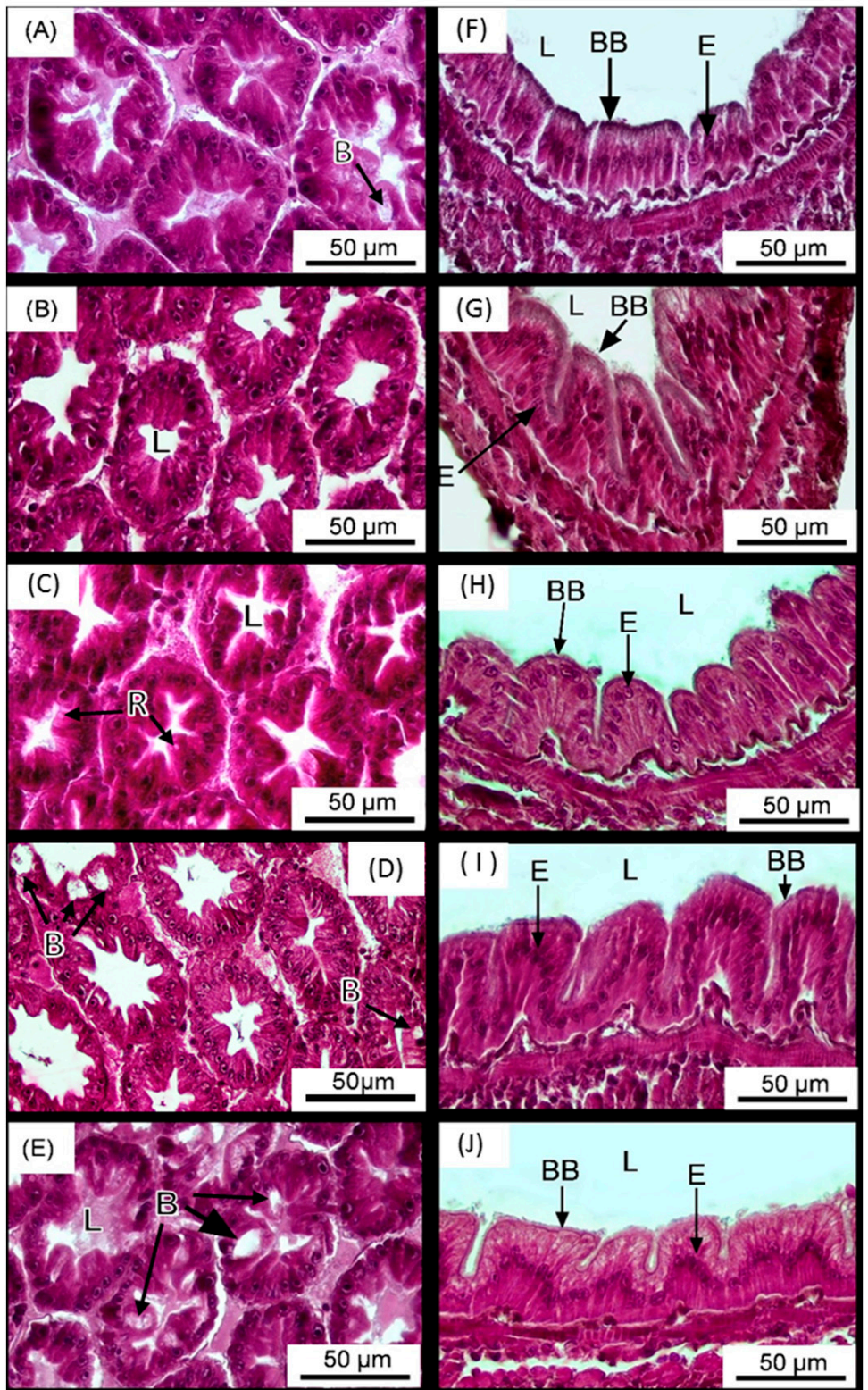

Figure 2. Histology sections (H\&E staining) of the hepatopancreas (A-E) and intestines (F-J) of Litopenaeus vannamei reared in the water supplemented with Micro-Aid Liquid 10 once per week at the levels of 0 (control) (A,F), $0.25 \mathrm{~mL} \mathrm{~m}^{3-1}$ (W0.25) (B,G), $0.5 \mathrm{~mL} \mathrm{~m}^{3-1}$ (W0.5) (C,H), $1 \mathrm{~mL} \mathrm{~m}^{3-1}$ (W1) $(\mathbf{D}, \mathbf{I})$ and $5 \mathrm{~mL} \mathrm{~m}^{3-1}$ (W5) (E,J), respectively. The letters in the figure indicated that: $\mathrm{L}$ (lumen), B (B cells), R (R cells), BB (brush border) and E (epithelium). $n=3$.

\subsection{Challenge Test}

The cumulative mortality of shrimp in different groups after being challenged with $V$. alginolyticus is illustrated in Figure 3. No dead shrimp was observed in the unchallenged control. Shrimp in the W1 and W5 groups had significantly lower cumulative mortality as compared to that of shrimp in the control, W0.25 and W0.5 groups.

\subsection{Intestinal Microbiota Counts}

The total bacterial counts in the intestine of shrimp were not significantly different among groups (Figure 4A). Despite the lower Vibrio-like counts in the groups of W0.25, W0.5, W1, and W5, the differences were not statistically different (Figure 4B). 


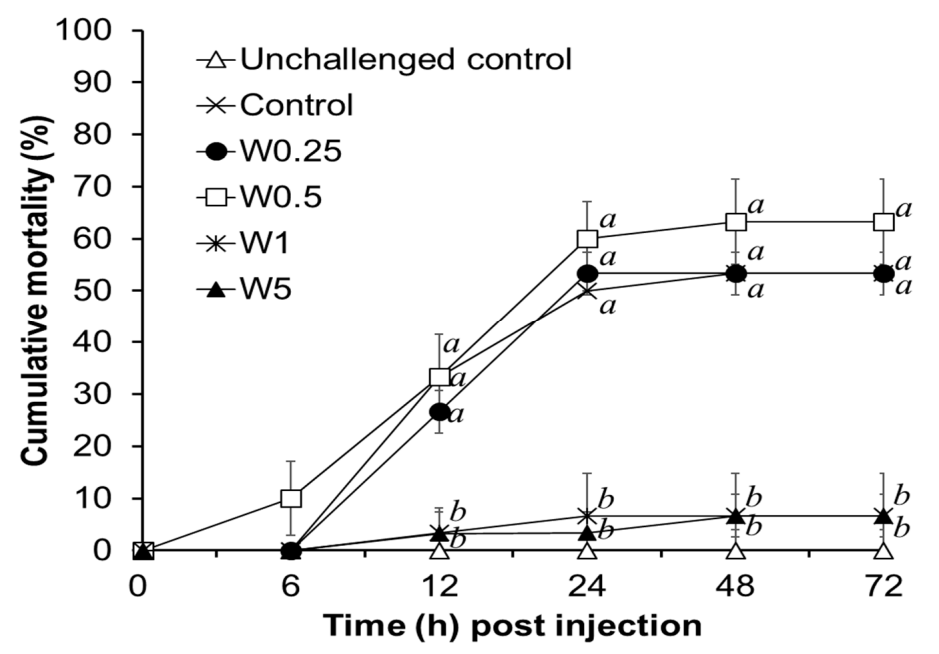

Figure 3. Cumulative mortality of shrimp reared in the water supplemented with different concentrations of Micro-Aid Liquid 10 (MAL10) after being challenged with pathogen, Vibrio alginolyticus for $72 \mathrm{~h}$. Data with different letters are significantly different among treatments $(p<0.05)$ (Data of unchallenged control were not included for the statistical analysis). W0.25, W0.5, W1, and W5 were $0.25,0.5,1$, and $5 \mathrm{~mL} \mathrm{~m}^{3-1}$ of MAL10, respectively. $n=3$.
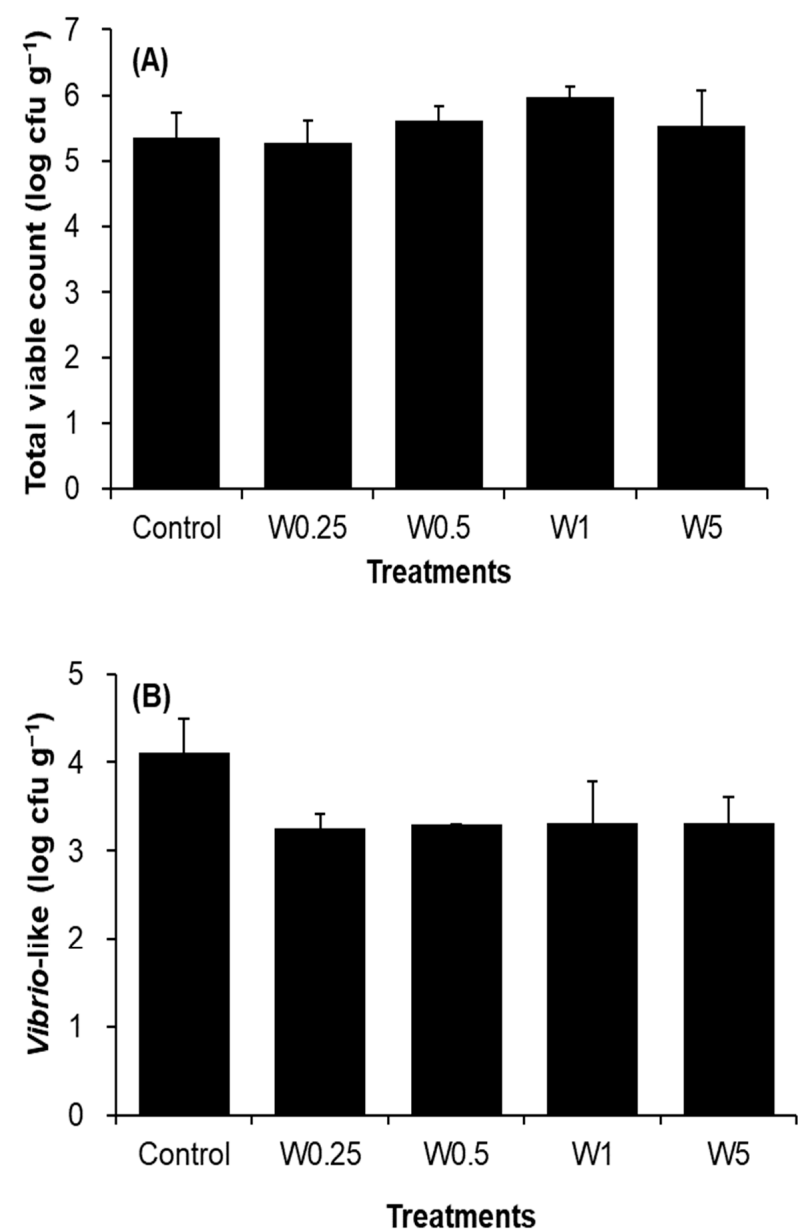

Figure 4. Total viable count (A) and Vibrio-like count $(\mathbf{B})$ in intestines of shrimp reared in the water added with Micro-Aid Liquid 10 once per week at the levels of 0 (control), $0.25 \mathrm{~mL} \mathrm{~m}^{3-1}$ (W0.25), $0.5 \mathrm{~mL} \mathrm{~m}^{3-1}$ (W0.5), $1 \mathrm{~mL} \mathrm{~m}^{3-1}$ (W1) and $5 \mathrm{~mL} \mathrm{~m}^{3-1}$ (W5), respectively. $n=3$. 


\subsection{Intestinal Microbiota Analysis by $16 S$ rDNA Next-Generation Sequencing}

Totally 326,622 and 549,023 non-redundant sequences were generated for the control and W5 groups, respectively. Sequences in the control and W5 groups were clustered into 775 and 956 OTUs, respectively, by an identity cutoff at $96 \%$. The OTUs obtained were then assigned to 10 phyla, 14 classes, 33 orders, 55 families, and 83 genera with taxonomic names (Figure 5). Shrimp intestinal sample in the control contained 63 genera. A slightly higher number of genera (67) was found in the intestine sample of shrimp in W5 group. Although shrimp in the W5 group had higher richness, evenness, Shannon index, and Simpson index than those of control shrimp, these differences were not statistically significant (Table 4).

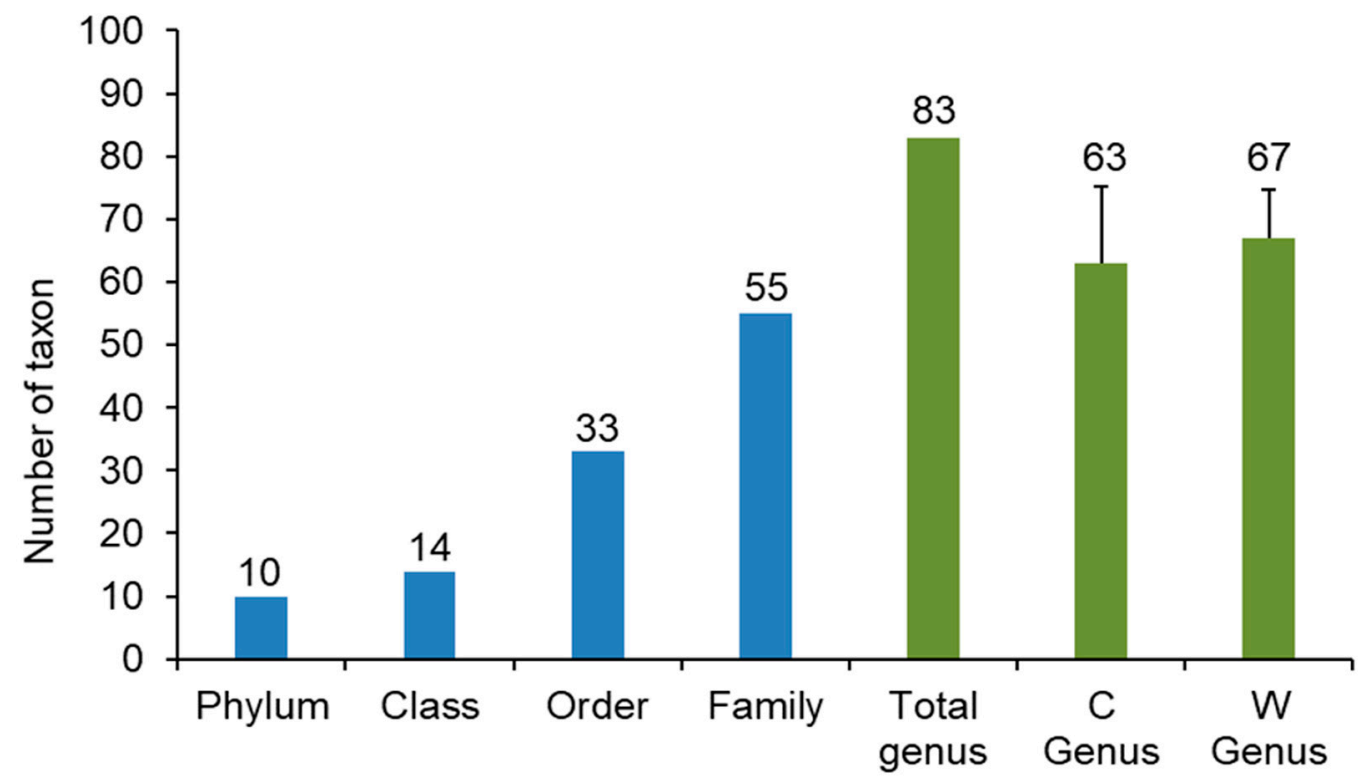

Figure 5. Microbial taxonomic identification in the gut of shrimp in control (C), and W5 (W) groups.

Table 4. $\alpha$-Diversity of the intestinal microbiota of shrimp in control (C), and W5 (W) groups. Values represent the mean diversity of triplicate replications within each group. $n=3$.

\begin{tabular}{cccccc}
\hline Treatments & Genus & $\begin{array}{c}\text { Margalef's Species } \\
\text { Richness (d) }\end{array}$ & $\begin{array}{c}\text { Pielou's } \\
\text { Evenness (J') }\end{array}$ & $\begin{array}{c}\text { Shannon } \\
\text { Index }\end{array}$ & $\begin{array}{c}\text { Simpson } \\
\text { Index }\end{array}$ \\
\hline C & 63 & $5.69 \pm 1.17$ & $0.38 \pm 0.1$ & $1.55 \pm 0.45$ & $0.58 \pm 0.16$ \\
W & 67 & $6.17 \pm 0.72$ & $0.43 \pm 0.12$ & $1.83 \pm 0.52$ & $0.65 \pm 0.16$ \\
\hline
\end{tabular}

Overall, the addition of MAL10 in water did not obviously influence the bacterial profile in shrimp's intestines because no distinct cluster was found in the PCA data (Figure 6). The contribution of principal component 1 (PC1) and PC2 was 29\% and 23.8\%, respectively, and together they explained $52.8 \%$ of the variation in the dataset. The relative abundances of distinct phyla in the shrimp intestines are demonstrated in Figure 7. The microbial taxonomic profile revealed that the Proteobacteria is the most abundant family in both groups at the phylum level. The control was the highest $(80.37 \%)$, followed by the W5 group (77.36\%). In addition to the Proteobacteria, relative abundances of the Bacteroidetes and Actinobacteria were found in both groups (12.95\% and $2.79 \%$, respectively for the control; and $7.94 \%$ and $9.32 \%$, respectively for the W5 group). The analysis of differences in detected bacteria by Venn diagrams at the generic level indicated that shared OTUs between control replicates (Figure 8A) and W5 replicates (Figure 8B) were 39 and 48, respectively. In addition, 27 OTUs were shared as core microbiota between the control and W5 groups (Figure 8C). Venn diagrams also show the taxonomic classifications of unique OTUs at the generic level. Twelve representative genera in the control were Novosphingobium, Neptunomonas, Qipengyuania, Tsukamurella, Methylobacterium, Bythopirellula, Planctomicrobium, Acinetobacter, 
Porphyrobacter, Lactobacillus, Brevibacillus, and Rheinheimera; 21 representative genera, including Streptococcus, Winogradskyella, Tenacibaculum, Halalkalicoccus, Methylophilus, Rubrobacter, Tabrizicola, Lawsonella, Rothia, Gordonia, Blastopirellula, Micrococcus, Achromobacter, Marinococcus, Brevibacterium, Corynebacterium, Thalassotalea, Taibaiella, Taeseokella, Delftia, and Labrenzia were unique in W5 group.

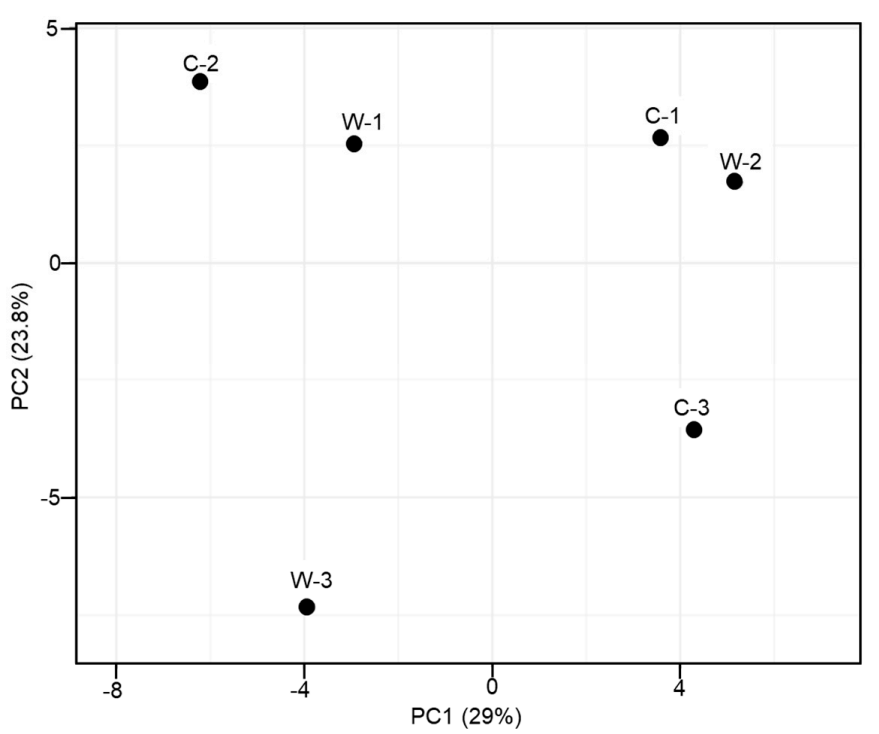

Figure 6. Comparison of PCA results at the generic level among the gut microbes of shrimp in control (C), and W5 (W) groups.

(A) C

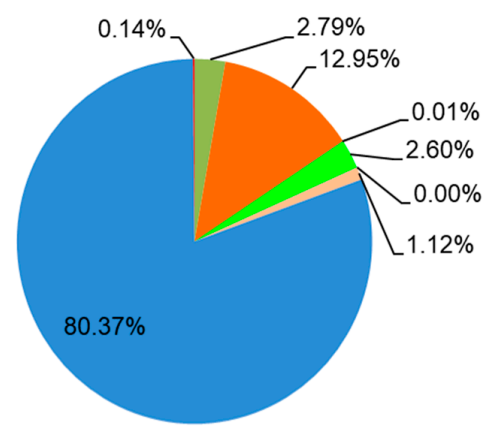

(B) $\mathrm{W}$
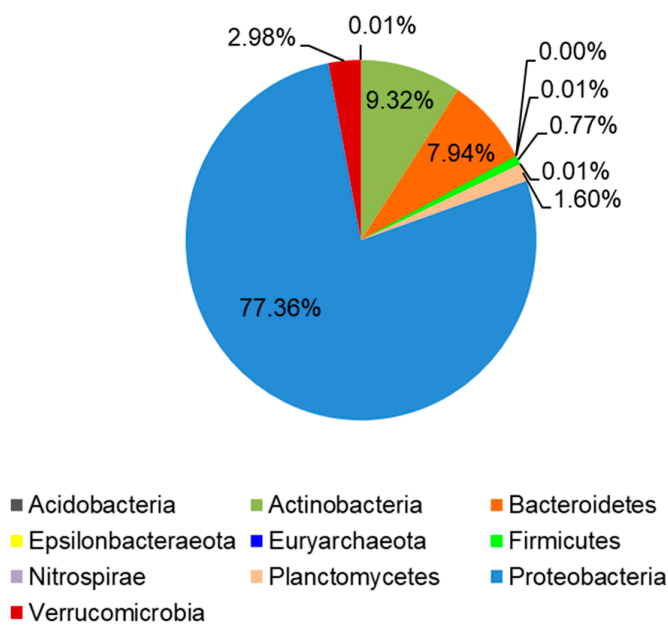

Figure 7. Average phylum distributions of intestinal microbiota of shrimp in control (A), and W5 (B) groups. 
(A)

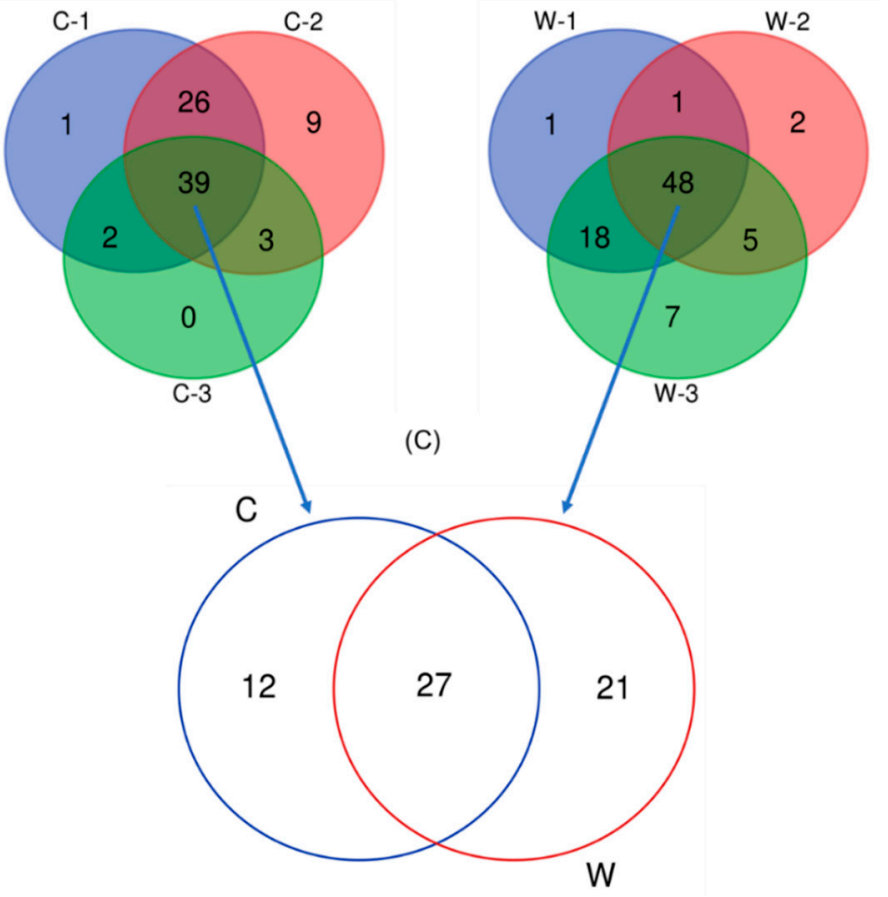

(B)

Figure 8. Venn diagrams represent the results of the core microbiota between replicates of each group $(\mathbf{A}, \mathbf{B})$, and between the control $(\mathbf{C})$, and W5 (W) groups $(\mathbf{C})$.

Taken together, the predominant genera (with the highest relative abundances) in shrimp intestines were Vibrio, Spongiimonas, Shewanella, Motilimonas, Demequina, and Pseudoaltreomonas. However, the relative abundances of the predominant genera varied among the various groups. Vibrio, Spongiimonas, Motilimonas, Paracoccus, and Shewanella were predominant genera in the control; while Vibrio, Sphingomonaas, Pseudoalteromonas, Motilimonas, Shewanella, and Demequina, were predominant in the W5 group (Figure 9).

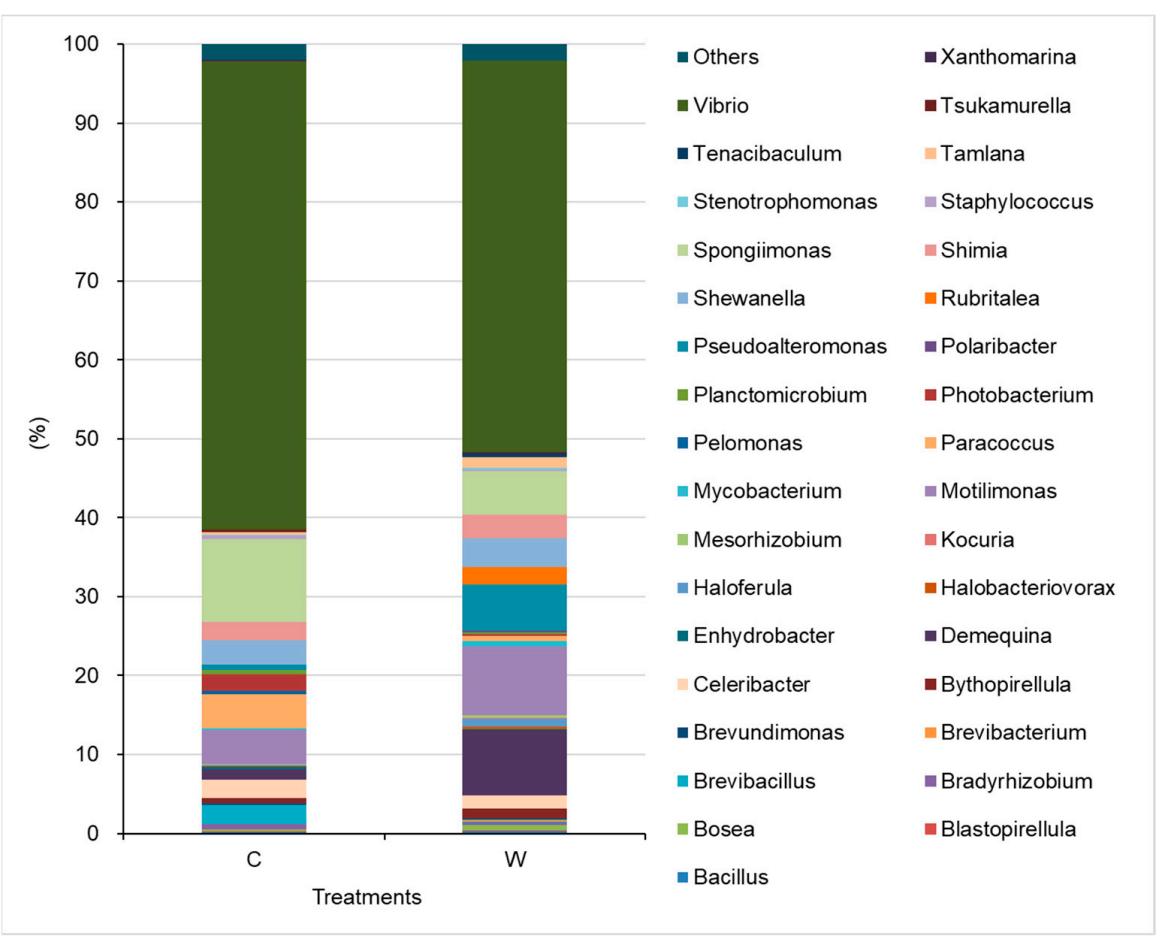

Figure 9. Relative abundances of bacteria identified at the generic level in the intestines of shrimp in control (C), and W5 (C) groups. 


\section{Discussion}

The use of saponin in aquaculture is considered advantageous in increasing growth performance [13]. In the current study, a commercially available saponin-based product, MAL 10, was applied to white shrimp culture pond, and the results showed that shrimp had improved growth performance. MAL 10 impact on the growth performance of shrimp may be associated with saponins' steroidal properties, which can change the cell membrane structure, alter microbial population, and enhance intestinal digestive enzymes, thereby reducing surface tension and promoting optimum utilization of nutrients $[10,13,16]$. Cattle treated by dietary Micro-aid for 59 days had increased average daily gain and feed efficiency [11]. Yang et al. [25] discovered that white shrimp fed diets with Y. schidigera extract (YSE) at the level of $0.2 \%$ for 100 days, had better growth performance, which might be due to YSE steroidal saponins and other surface-active substances, which promoted nutrient absorption. Hernández-Acosta et al. [10] investigated the effects of both Y. schidigera and Q. saponaria extracts (NTF) on growth performance and enzymatic activities of juvenile white shrimp cultured in low salinity water. The results indicated an increase in final mean body weight, individual weight gain, weight gain, and specific growth rate, and a decrease in FCR when shrimp were treated with NTF at $1-2 \mathrm{~g} \mathrm{~kg}^{-1}$. In addition, the activities of digestive enzymes, including alkaline protease, lipase, $\alpha$-amylase, leucine aminopeptidase, and alkaline phosphatase, were also improved by NTF. The improved activities of digestive enzymes in shrimp influenced by NTF were possibly due to the histological changes in shrimp's hepatopancreas (the main digestive organ of shrimp), as well as the finding in this study, which demonstrated an increase in B cells in shrimps reared in the water supplemented with MAL10. It is well known that the B cell is the main site of nutrient absorption and digestion $[26,27]$. Therefore, the increased number of $B$ cells in the hepatopancreas of shrimp reared in the water supplemented with MAL10 up to $5 \mathrm{~mL} \mathrm{~m}^{3-1}$ likely contributed to increased digestion and absorption of nutrients. However, the mechanism involved with the increased number of B cells in shrimp's hepatopancreas caused by MAL10 needs further study.

Saponins, including the saponin-based product MAL10 extracted from Y. schidigera modulate animals' health status, has been demonstrated in several studies [7,11]. The most studied saponins derived from the soap tree, $Q$. saponaria were used as a vaccine adjuvant [28]. Maharaj et al. [29] indicated that oral administration of Quillaja saponin preparation either before or with inactivated rabies vaccine resulted in increased protection compared to administration of vaccine alone. Although antibody titers are lower than intraperitoneally vaccinated animals, they remained high for six months following vaccination. Fish's immune responses can also be effectively elicited by saponins [30], such as Quillaja saponin, enhancing chemotactic activity of head kidney leukocytes of yellowtail after oral administration [31]. Wang et al. [32] reported that dietary YSE could increase the lysozyme activity of mirror carp, Cyprinus carpio at 200 and $400 \mathrm{mg} / \mathrm{kg}$ of YSE and increase complements 3 and 4 at $400 \mathrm{mg} / \mathrm{kg}$ of YSE. Immunomodulatory effects were also found in white shrimp immersed in water supplemented with saponin at $2 \mathrm{mg} \mathrm{L}^{-1}$ or less, including increased hyaline cells, total hemocyte count, specific $\alpha 2$-macroglobulin activity, respiratory burst, superoxide dismutase activity, glutathione peroxidase activity, and phagocytic activity as well as protection against $V$. alginolyticus infection [7]. In this study, MAL10 also enhanced white shrimps' disease resistance against infection by $V$. alginolyticus, which might also be due to an increase of immune response, although shrimp's immune status was not assessed.

Gut microbiota is considered an important driver of several metabolic processes that might be involved with the growth and health of hosts [33]. A deeper assessment of the profile and role of an animal's microbiome in its development and health status using the high-throughput sequencing of $16 \mathrm{~S}$ rDNA is becoming more popular in recent years. It is well known that the composition of microbiota in aquatic animals' gut is influenced by factors, such as the environment [34]. Therefore, good environmental conditions that would modify the gut microbial community and evoke positive effects on the health 
and survival of shrimp are vital [35]. Y. shidigera extract has been proven effective in reducing ammonia [36] and altering microbial structure in the environment or gut of the host $[37,38]$. For example, saponins from Quillaja and Yucca can modulate ruminal microbial communities in a dose-dependent manner and improve feed utilization and growth [38,39]. Similarly, the saponin-based product MAL10 altered gut microbiota of shrimp by reducing potential pathogens and increasing beneficial microbes thereby, improving the growth performance and disease resistance in this study.

Proteobacteria is the most dominant phyla in shrimp guts at all growth stages $[40,41]$. The phylum Proteobacteria accounted for $80.7 \sim 98.5 \%$ of the total, while Firmicutes only accounted for $0.05 \sim 0.2 \%$ of the total in gut of tiger shrimp, Penaeus monodon [42]. The Proteobacteria is also the predominant phylum in white shrimp, accounting for $51.1 \%$ of all bacterial communities [43]. In our previous study, $16 \mathrm{~S}$ rDNA amplicon sequencing results also indicated that Proteobacteria is the predominant phylum, accounting for $49.41 \sim 88.08 \%$ in the gut of shrimps in the control and probiotic-treated shrimp [40], which agrees with the findings in this study. However, the phylum Proteobacteria and the number of Vibrio spp. (belonging to the Proteobacteria) were reduced in W5 group in comparison with the control, indicating a lower risk of shrimp disease.

Some unique genera in the gut of shrimp after W5 treatment were recorded in this study. Among the unique genera in the W5 group, Methylophilus bacteria have been used as a single cell protein in aquatic animals and are considered a protein-rich ingredient [44]. Kant [45] also suggested that bacteria like Pseudomonas and Methylophilus spp. can be used as single cell protein in aquafeed, composed of $\sim 73 \mathrm{~g} \mathrm{~kg}^{-1}$ crude protein, $5.7 \mathrm{~g} \mathrm{~kg}^{-1} \mathrm{lipid}_{\text {, }}$ and $2.7 \mathrm{~g} \mathrm{~kg}^{-1}$ nitrogen free extract by weight. High levels of good quality protein can provide important nutrients for aquacultural animals. Gordonia is another beneficial genus for aquaculture species, which was found in the W5 group in addition to Actinomycetales that both possess a robust cell wall-associated with adjuvants. Adjuvants of Gordonia bronchialis are immunomodulatory like Mycobacterium vaccae. As in mammals, G. bronchialis is known to have benefits in growth performance, intestinal structure, and antioxidative defense responses of rainbow trout, Oncorhynchus mykiss [46]. Brevibacterum casei MSI04 isolated from a marine sponge can produce a poly-hydroxy butyrate polymer with antiadhesive activity up to $96 \%$ that was recorded against $V$. vulnificus, and $V$. fischeri, followed by $92 \%$ against $V$. parahaemolyticus and $V$. alginolyticus, and $88 \%$ inhibition was recorded against $V$. harveyi [47]. Thus, Brevibacterium only found in the W5 group reduces the risk of vibriosis in shrimp aquaculture. In addition to the abovementioned unique genera in the W5 group, some beneficial bacteria, such as Streptococcus, Micrococcus, and Corynebacterium for humans or aquatic animals [48-50] were also only found in the W5 group. The number of beneficial bacteria is higher in the W5 group, indicating that adding MAL10 into the water may alter the profile of environmental microflora and change the intestinal microbiota in shrimp. Consequently, shrimp in the W5 group had better growth performance and health status.

Vibrio spp. is typically among the most abundant flora in shrimp gut $[40,51]$ and pathogenic in shrimp aquaculture [52-54]. Vibrio is the predominant flora at all stages of shrimp, from the post-larval stage [41] to the growth stage [40]. In this study, Vibrio spp. were also predominant in shrimp gut, accounting for $49.6 \sim 59.3 \%$ of the microbiota. In addition to Vibrio, Photobacterium is also a pathogen that causes serious disease for shrimp [55], such as Photobacterium damselae subsp. damselae, a causative agent of myonecrosis and hepatopancreatic necrosis, posing a threat to shrimp hatcheries in India [56]. Reduction in endemic pathogenic bacteria in shrimp intestines can lead to a decrease in disease outbreaks caused by Vibrio infections $[57,58]$. In addition to the aforementioned pathogens, some beneficial bacteria, including Demequina, Pseudoalteromonas, Shewanella, and Rubritalea increased in the intestine of shrimp in the W5 group compared to shrimp in the control. Demequina, an $\alpha$-amylase producing bacterium involved with carbohydrate utilization [59]. Rubritalea can produce antioxidative Glyco-G30 carotenoic acids and has potent antioxidative activity [60]. Shewanella algae isolated from the intestine of healthy tiger shrimp can protect 
against the infection of Aeromonas hydrophila [61]. Similarly, Pseudoalteromonas CDM8 and CDA22 isolated from healthy tiger shrimp are potential biological control agents protecting against acute hepatopancreatic necrosis disease (AHPND)-causing V. parahaemolyticus [62]. Therefore, the results from the altered gut microbiota structure suggest that MAL10 can reduce the abundances of potential pathogens, increase the beneficial bacteria, and further reduce the risk of diseases and increase the growth performance or health status of shrimp.

\section{Summary}

In the case of MAL10, growth performance of shrimp reared in water supplemented with this product ranged from 0.25 to $5 \mathrm{~mL} \mathrm{~m}^{3-1}$ once per week was significantly improved in a dose-dependent manner. This might have resulted from the increased number of $B$ cells in the hepatopancreas, as observed in histopathological examination. In addition, adding MAL10 at higher concentrations (W1 and W5) significantly increased the resistance to pathogens. The $16 \mathrm{~S}$ rDNA amplicons sequencing revealed that MAL10 (W5) application increased beneficial bacteria and reduced pathogens in the intestinal microbiota of shrimp treated by MAL10, which might be involved with increased disease resistance and growth performance of shrimp.

Author Contributions: Investigation, K.-C.H., Y.-L.S., R.B.; Data curation, K.-C.H.; Conceptualization, Y.-L.S.; English editing, R.B.; Writing-Reviewing and Editing, C.-H.L.; Conceptualization, C.-H.L.; Funding acquisition, J.-W.L. All authors have read and agreed to the published version of the manuscript.

Funding: DPI Global (Porterville, CA) and the Ministry of Science and Technology, Taiwan (110-2313B-020-006-MY3).

Institutional Review Board Statement: Not applicable.

Informed Consent Statement: Not applicable.

Data Availability Statement: The data that support the findings of this study are available from the corresponding author upon reasonable request.

Acknowledgments: The authors also appreciate the kind help of Rolissa Ballantyne for editing the English in this manuscript.

Conflicts of Interest: The authors declare no conflict of interest.

\section{References}

1. FAO. The State of World Fisheries and Aquaculture 2020 Sustainability in Action; FAO: Rome, Italy, 2020.

2. Mirbakhsh, M.; Akhavan-Sepahy, A.; Afsharnasab, M.; Khanafari, A.; Razavi., M.R. Molecular identification of Vibrio harveyi from larval stage of pacific white shrimp (Litopenaeus vannamei) boone (Crustacea: Decapoda) by polymerase chain reaction and $16 \mathrm{~S}$ rDNA sequencing. Iran. J. Fish. Sci. 2014, 13, 384-393.

3. Jayasree, L.; Janakiram, P.; Madhavi, R. Characterization of Vibrio spp. associated with diseased shrimp from culture ponds of Andhra Pradesh (India). J. World Aquac. Soc. 2006, 37, 523-532. [CrossRef]

4. Vandenberghe, J.; Verdonck, L.; Robles-Arozarena, R.; Rivera, G.; Bolland, A.; Balladares, M.; Gómez-Gil, B.; Sorgeloos, P.; Swings, J. Vibrios associated with Litopenaeus vannamei larvae, postlarvae, broodstock, and hatchery probionts. Appl. Environ. Microbiol. 1999, 65, 2592-2597. [CrossRef] [PubMed]

5. Direkbusarakom, S. Application of medicinal herbs to aquaculture in Asia. Walailak J. Sci. Tech. 2004, 1, 7-14.

6. Yilmaz, E.; Tasbozan, O.; Erbas, C. Potential of medical herbal products to be used in aquaculture. EAJS 2018, 4, 16-23.

7. Su, B.K.; Chen, J.C. Effect of saponin immersion on enhancement of the immune response of white shrimp Litopenaeus vannamei and its resistance against Vibrio alginolyticus. Fish Shellfish Immunol. 2008, 24, 74-81. [CrossRef]

8. Ng'ambi, J.W.; Li, R.; Mu, C.; Song, W.; Liu, L.; Wang, C. Dietary administration of saponin stimulates growth of the swimming crab Portunus trituberculatus and enhances its resistance against Vibrio alginolyticus infection. Fish Shellfish Immunol. 2016, 59, 305-311. [CrossRef]

9. Awad, E.; Awaad, A. Role of medicinal plants on growth performance and immune status in fish. Fish Shellfish Immunol. 2017, 67, 40-54. [CrossRef] 
10. Hernández-Acosta, M.; Gutiérrez-Salazar, G.J.; Guzmán-Sáenz, F.M.; Aguirre-Guzmán, G.; Alvarez-González, C.A.; López-Acevedo, E.A.; Fitzsimmons, K. The effects of Yucca schidigera and Quillaja saponaria on growth performance and enzymes activities of juvenile shrimp Litopenaeus vannamei cultured in low-salinity water. Lat. Am. J. Aquat. Res. 2016, 44, 121-128. [CrossRef]

11. Schubach, K.M.; Cooke, R.F.; Brandão, A.P.; de Sousa, O.A.; Schumaher, T.F.; Bohnert, D.W.; Marques, R.S. Supplementing Micro-Aid to optimize health and performance of receiving cattle. Transl. Anim. Sci. 2018, 2, S22-S26. [CrossRef]

12. Cañon-Jones, H.; Cortes, H.; Castillo-Ruiz, M.; Schlotterbeck, T.; Martín, R.S.M. Quillaja saponaria (Molina) extracts inhibits in vitro Piscirickettsia salmonis infections. Animals 2020, 10, 2286. [CrossRef] [PubMed]

13. Francis, G.; Makkar, H.P.S.; Becker, K. Quillaja saponins-A natural growth promoter for fish. Anim. Feed Sci. Technol. 2005, 121, 147-157. [CrossRef]

14. Saeed, M.; Arain, M.A.; Naveed, M.; Alagawany, M.; El-Hack, M.E.A.; Bhutto, Z.A.; Bednarczyk, M.; Kakar, M.U.; Latif, M.A.; Chao, S. Yucca schidigera can mitigate ammonia emissions from manure and promote poultry health and production. Environ. Sci. Pollut. Res. 2018, 25, 35027-35033. [CrossRef]

15. Santacruz-Reyes, R.A.; Chien, Y.H. The potential of Yucca schidigera extract to reduce the ammonia pollution from shrimp farming. Bioresour. Technol. 2012, 113, 311-314. [CrossRef] [PubMed]

16. Moses, T.; Papadopoulou, K.K.; Osbourn, A. Metabolic and functional diversity of saponins, biosynthetic intermediates and semi-synthetic derivatives. Crit. Rev. Biochem. Mol. Biol. 2014, 49, 439-462. [CrossRef]

17. Su, J.L.; Shi, B.L.; Zhang, P.F.; Sun, D.S.; Li, T.Y.; Yan, S.M. Effects of yucca extract on feed efficiency, immune and antioxidative functions in broilers. Braz. Arch. Biol. Technol. 2016, 59, 16150035. [CrossRef]

18. Gaber, M.M. The effects of plant-protein-based diets supplemented with Yucca on growth, digestibility, and chemical composition of Nile tilapia (Oreochromis niloticus L.) fingerlings. J. World Aquac. Soc. 2006, 37, 74-81. [CrossRef]

19. Moreau, R.A.; Whitaker, B.D.; Hicks., K.B. Phytosterols, phytostanols, and their conjugates in foods: Structural diversity, quantitative analysis, and health-promoting uses. Prog. Lipid Res. 2020, 41, 457-500. [CrossRef]

20. Lin, J.C.; Cheng, A.C.; Shiu, Y.L.; Wong, Y.C.; Yeh, S.P.; Simangunsong, T.; Liu, C.H. Using the biochar produced from spend mushroom substrate to improve the environmental condition of aquaculture pond. Aquac. Res. 2021, 52, 3532-3539. [CrossRef]

21. Tseng, D.Y.; Hsieh, S.C.; Wong, Y.C.; Hu, S.Y.; Hsieh, J.M.; Chiu, S.T.; Yeh, S.P.; Liu, C.H. Chitin derived from Daphnia similis and its derivate, chitosan, promote growth performance of Penaeus vannamei. Aquaculture 2021, 531, 735919. [CrossRef]

22. Liu, C.H.; Cheng, W.; Hsu, J.P.; Chen, J.C. Vibrio alginolyticus infection in the white shrimp Litopenaeus vannamei confirmed by polymerase chain reaction and 16S rDNA sequencing. Dis. Aquat. Org. 2004, 61, 169-174. [CrossRef] [PubMed]

23. Klindworth, A.; Pruesse, E.; Schweer, T.; Peplies, J.; Quast, C.; Horn, M.; Glöckner, F.Q. Evaluation of general 16S ribosomal RNA gene PCR primers for classical and next generation sequencing based diversity studies. Nucleic Acids Res. 2013, 41, e1. [CrossRef] [PubMed]

24. Huynh, T.G.; Hu, S.Y.; Chiu, C.H.; Truong, Q.P.; Liu, C.H. Bacterial population in intestines of white shrimp, Litopenaeus vannamei fed a synbiotic containing Lactobacillus plantarum and galactooligosaccharide. Aquac. Res. 2019, 50, 807-817. [CrossRef]

25. Yang, Q.H.; Tan, B.P.; Dong, X.H.; Chi, S.Y.; Liu, H.Y. Effects of different levels of Yucca schidigera extract on the growth and nonspecific immunity of Pacific white shrimp (Litopenaeus vannamei) and on culture water quality. Aquaculture 2015, 439, 39-44. [CrossRef]

26. Al-Mohanna, S.Y.; Nott, J.A. R-cells and the digestive cycle in Penaeus semisulcatus (Crustacea: Decapoda). Mar. Biol. 1987, 9 , 129-137. [CrossRef]

27. Silva, M.A.S.; Neto, A.; Ramiro, B.O.; Santos, I.T.F.; Guerra, R.R. Histomorphologic characterization of the hepatopancreas of freshwater prawn Macrobrachium rosenbergii (De Man, 1879). Arq. Bras. Med. Vet. Zootec. 2018, 70, 1539-1546. [CrossRef]

28. Rajput, Z.I.; Hu, S.H.; Xiao, C.W.; Arijo, A.G. Adjuvant effects of saponins on animal immune responses. J. Zhejiang Univ. Sci. B 2007, 8, 153-161. [CrossRef]

29. Maharaj, I.; Froh, K.J.; Campbell, J.B. Immune responses of mice to inactivated rabies vaccine administered orally potentiation by Quillaja saponin. Can. J. Microbiol. 1986, 32, 414-420. [CrossRef]

30. Ashida, T.; Okimasu, E.; Amemura, A. Decrease in mortality of yellowtail Seriola quinqueradiata due to Enterococcus seriolicida infection by feeding of saponins, and expression of hsp60 in kidney. Fish. Sci. 1999, 65, 490-491. [CrossRef]

31. Ninomiya, M.; Hatta, H.; Fujiki, M.; Kim, M.; Yamamoto, T.; Kusada, R. Enhancement of chemotactic activity of yellowtail (Seriola quinqueradiata) leucocytes by oral administration of quillaja saponin. Fish Shellfish Immunol. 1995, 5, 325-328. [CrossRef]

32. Wang, L.; Wu, D.; Fan, Z.; Li, H.; Li, J.; Zhang, Y.; Xu, Q.; Wang, G.; Zhu, Z. Effect of Yucca schidigera extract on the growth performance, intestinal antioxidant status, immune response, and tight junctions of mirror carp (Cyprinus carpio). Fish Shellfish Immunol. 2020, 103, 211-219. [CrossRef] [PubMed]

33. Hou, D.; Huang, Z.; Zeng, S.; Liu, J.; Wei, D.; Deng, X.; Weng, S.; Yan, Q.; He, J. Intestinal bacterial signatures of white feces syndrome in shrimp. Appl. Microbiol. Biotechnol. 2018, 102, 3701-3709. [CrossRef] [PubMed]

34. Cornejo-Granados, F.; Lopez-Zavala, A.A.; Gallardo-Becerra, L.; Mendoza-Vargas, A.; Sánchez, F.; Vichido, R.; Brieba, L.G.; Viana M.T.; Sotelo-Mundo, R.R.; Ochoa-Leyva, A. Microbiome of Pacific Whiteleg shrimp reveals differential bacterial community composition between Wild, Aquacultured and AHPND/EMS outbreak conditions. Sci. Rep. 2017, 7, 11783. [CrossRef] [PubMed]

35. Zeng, S.; Huang, Z.; Hou, D.; Liu, J.; Weng, S.; He, J. Composition, diversity and function of intestinal microbiota in pacific white shrimp (Litopenaeus vannamei) at different culture stages. PeerJ 2017, 5, e3986. [CrossRef] 
36. Yu, X.; Dimitriou, E.; Konstantinos, S.; Markogianni, V.; Politi, D. Effects of Yucca schidigera extract on the reduction of ammonia concentration in lake Koumoundourou. J. Ecol. Eng. 2015, 16, 1-7. [CrossRef]

37. Wallace, R.J.; Arthaud, L.; Newbold, C.J. Influence of Yucca schidigera extract on ruminal ammonia concentrations and ruminal microorganisms. Appl. Environ. Microbiol. 1994, 60, 1762-1767. [CrossRef] [PubMed]

38. Patra, A.K.; Stiverson, J.; Yu, Z. Effects of quillaja and yucca saponins on communities and select populations of rumen bacteria and archaea, and fermentation in vitro. J. Appl. Microbiol. 2012, 113, 1329-1340. [CrossRef]

39. Wang, J.K.; Ye, J.A.; Liu, J.X. Effects of tea saponins on rumen microbiota, rumen fermentation, methane production and growth performance-A review. Trop. Anim. Health Prod. 2012, 44, 697-706. [CrossRef]

40. Chiu, S.T.; Chu, T.W.; Simangunsong, T.; Ballantyne, R.; Chiu, C.S.; Liu, C.H. Probiotic, Lactobacillus pentosus BD6 boost the growth and health status of white shrimp, Litopenaeus vannamei via oral administration. Fish Shellfish Immunol. 2021, 117, 124-135. [CrossRef]

41. Huang, Z.; Li, X.; Wang, L.; Shao, Z. Changes in the intestinal bacterial community during the growth of white shrimp, Litopenaeus vannamei. Aquac. Res. 2016, 47, 1737-1746. [CrossRef]

42. Rungrassamee, W.; Klanchui, A.; Chaiyapechara, S.; Maibunkaew, S.; Tangphatsornruang, S.; Jiravanichpaisal, P.; Karoonuthaisiri, N. Bacterial population in intestines of the black tiger shrimp (Penaeus monodon) under different growth stages. PLoS ONE 2013, 8, e60802. [CrossRef]

43. Shao, J.; Wang, B.; Liu, M.; Jiang, K.; Wang, L.; Wang, M. Replacement of fishmeal by fermented soybean meal could enhance the growth performance but not significantly influence the intestinal microbiota of white shrimp Litopenaeus vannamei. Aquaculture 2019, 504, 354-360. [CrossRef]

44. Tacon, A.G.J.; Metian, M.; Hasan, M.R. Feed Ingredients and Fertilizers for Farmed Aquatic Animals. Sources and Composition; FAO Fisheries and Aquaculture technical paper; FAO: Roma, Italy, 2009; p. 540.

45. Kant, S. Potentiality of single cell protein (SCP) for aquafeed. Fish. Chimes 1996, 14, 35-37.

46. Shabanzadeh, S.; Shapoori, M.; Sheikhzadeh, N.; Nofouzi, K.; Oushani, A.K.; Enferadi, M.H.N.; Mardani, K.; Shahbazfar, A.A. Growth performance, intestinal histology, and biochemical parameters of rainbow trout (Oncorhynchus mykiss) in response to dietary inclusion of heat-killed Gordonia bronchialis. Fish Physiol. Biochem. 2016, 42, 65-71. [CrossRef] [PubMed]

47. Kiran, G.S.; Lipton, A.N.; Priyadharshini, S.; Anitha, K.; Suárez, L.E.C.; Arasu, M.V.; Choi, K.C.; Selvin, J.; Al-Dhabi, N.A. Antiadhesive activity of poly-hydroxy butyrate biopolymer from and marine Brevibacterium casei MSI04 against shrimp pathogenic vibrios. Microb. Cell Fact. 2014, 13, 114. [CrossRef] [PubMed]

48. Lara-Flores, M.; Olvera-Novoa, M.A.; Guzmán-Méndez, B.E.; Madrid, W.L. Use of the bacteria Streptococcus faecium and Lactobacillus acidophilus, and the yeast Saccharomyces cerevisiae as growth promoters in Nile tilapia (Oreochromis niloticus). Aquaculture 2003, 216, 193-201. [CrossRef]

49. Sharma., R.; Bhaskar, B.; Sanodiya, B.S.; Thakur, G.S.; Jaiswal, P.; Yadav, N.; Sharma, A.; Bisen, P.S. Probiotic efficacy and potential of Streptococcus thermophiles modulating human health: A synoptic review. IOSR J. Pharm. Biol. Sci. 2014, 9, 52-58.

50. Burkovski, A. Corynebacterium pseudodiphtheriticum: Putative probiotic, opportunistic infector, emerging pathogen. Virulence 2015, 6, 673-674. [CrossRef]

51. Moss, S.; LeaMaster, B.; Sweeney, J. Relative abundance and species composition of Gram-negative, aerobic bacteria associated with the gut of juvenile white shrimp Litopenaeus vannamei reared in oligotrophic well water and eutrophic pond water. J. World Aquac. Soc. 2000, 31, 255-263. [CrossRef]

52. Lavilla-Pitogo, C.R.; Leano, E.M.; Paner, M.G. Mortalities of pond-cultured juvenile shrimp Penaeus monodon associated with dominance of luminescent vibrios in the rearing environment. Aquaculture 1998, 164, 337-349. [CrossRef]

53. Tsai, C.Y.; Santos, H.M.; Hu, S.Y.; Yanuaria, C.A.S.; Lola, E.N.G.; Tayo, L.L.; Nitura, K.M.A.; Liu, C.H.; Chuang, K.P. LpxD gene knockout elicits protection to Litopenaeus vannamei, white shrimp, against Vibrio parahaemolyticus infection. Aquac. Int. 2019, 27, 1383-1393. [CrossRef]

54. Cheng, A.C.; Shiu, Y.L.; Chiu, S.T.; Ballantyne, R.; Liu, C.H. Effects of chitin from Daphnia similis and its derivative, chitosan on the immune response and disease resistance of white shrimp, Litopenaeus vannamei. Fish Shellfish Immunol. 2021, 119, 329-338 [CrossRef]

55. Liu, F.; Liu, G.; Li, F. Characterization of two pathogenic Photobacterium strains isolated from Exopalaemon carinicauda causing mortality of shrimp. Aquaculture 2016, 464, 129-135. [CrossRef]

56. Singaravel, V.; Gopalakrishnan, A.; Dewangan, N.K.; Kannan, D.; Shettu, N.; Martin, G.G. Photobacterium damselae subsp. damselae associated with bacterial myonecrosis and hepatopancreatic necrosis in broodstock Pacific white leg shrimp, Litopenaeus vannamei (Boone, 1931). Aquac. Int. 2020, 28, 1593-1608. [CrossRef]

57. Cheng, A.C.; Yeh, S.P.; Hu, S.Y.; Lin, H.L.; Liu, C.H. Intestinal microbiota of white shrimp, Litopenaeus vannamei, fed diets containing Bacillus subtilis E20-fermented soybean meal (FSBM) or an antimicrobial peptide derived from B. subtilis E20-FSBM Aquac. Res. 2020, 51, 41-50. [CrossRef]

58. Cheng., A.C.; Lin, H.L.; Shiu, Y.L.; Tyan, Y.C.; Liu, C.H. Isolation and characterization of antimicrobial peptides derived from Bacillus subtilis E20-fermented soybean meal and its use for preventing Vibrio infection in shrimp aquaculture. Fish Shellfish Immunol. 2017, 67, 270-279. [CrossRef] [PubMed]

59. Al-Naamani, L.; Dobretsov, S.; Al-Sabahi, J.; Soussi, B. Identification and characterization of two amylase producing bacteria Cellulosimicrobium sp. and Demequina sp. isolated from marine organisms. J. Agric. Mar. Sci. 2015, 20, 8-15. 
60. Shindo, K.; Asagi, E.; Sano, A.; Hotta, E.; Minemura, N.; Mikami, K.; Tamesada, E.; Misawa, N.; Maoka, T. Diapolycopenedioic acid xylosyl esters $\mathrm{A}, \mathrm{B}$, and $\mathrm{C}$, novel antioxidative Glyco- $\mathrm{C}_{30}$-carotenoic acids produced by a new marine bacterium Rubritalea squalenifaciens. J. Antibiot. 2008, 61, 185-191. [CrossRef]

61. Ariole, C.N.; Ekeke, J.I. Studies on an indigenous probiotic (Shewanella algae) isolated from healthy shrimp intestine. Int. J. Mar. Sci. 2016, 59, 1-8.

62. Wang, H.; Wang, C.; Tang, Y.; Sun, B.; Huang, J.; Song, X. Pseudoalteromonas probiotics as potential biocontrol agents improve the survival of Penaeus vannamei challenged with acute hepatopancreatic necrosis disease (AHPND)-causing Vibrio parahaemolyticus. Aquaculture 2018, 494, 30-36. [CrossRef] 